УДК 349.232

DOI https://doi.org/10.32837/yuv.v0i4.2235

Т. Масалова,

аспірантка кафедри цивільно-правових дисциплін, господарського та трудового права

Харківського національного педагогічного університету імені Г. С. Сковороди

\title{
ДО ПИТАННЯ ПОНЯТТЯ ГРОШОВОГО ЗАБЕЗПЕЧЕННЯ ПОЛІЦЕЙСЬКИХ
}

\begin{abstract}
Постановка проблеми. Поліцейські посідають чільне місце поміж суб'єктів, які нині потребують соціального захисту, що зумовлено специфікою покладених на них завдань і функцій. Від рівня соціального захисту поліцейського залежить результативність діяльності Національної поліції як правоохоронного органу загалом. Соціальний захист поліцейських потребує особливої уваги, адже йдеться про вагомий чинник мотивування поліцейського до виконання своїх завдань на високому професійному рівні, самовіддано й максимально ефективно.

Соціальний захист поліцейських це напрям державної політики, який передбачає матеріальне забезпечення цієї категорії громадян у разі виникнення соціального ризику за кошти Державного бюджету. Основним елементом у структурі матеріального забезпечення поліцейських є їхнє грошове забезпечення. Сутність і значення поняття «грошове забезпечення поліцейських» неодноразово ставало об’єктом дослідження у працях вітчизняних та зарубіжних науковців. Незважаючи на це, багато питань ще потребують свого вирішення з огляду на законодавчі зміни.
\end{abstract}

Мета дослідження - аналіз поглядів науковців та чинного законодавства щодо сутності грошового забезпечення поліцейських i формулювання відповідних висновків.

Аналіз останніх досліджень. Проблемам реалізації конституцій- ного права на оплату праці приділялася значна увага в наукових роботах таких фахівців у галузі трудового права, як В. M. Андріїв, О. С. Арсентьєва, О. В. Валецька, H. M. Вапнярчук, В. M. Вегера, Ю. М. Верес, О. В. Гаєвая, А. О. Гордеюк, Я. В. Красько, І. П. Лаврінчук, Р. 3. Лівшиц, О. В. Москаленко, А. Ю. Пашерстник, О. I. Процевський, В. Г. Руденко, Н. В. Сазанова, І. Ю. Сафронов, Я. В. Сімутіна, K. Є. Шевелев, Г. І. Чанишева, О. М. Ярошенко та інші.

Виклад основного матеріалу. Однією з найважливіших юридичних гарантій реалізації права на працю $€$ можливість працездатної особи заробляти працею собі на життя. Ігнорування цієї гарантії на підприємствах, в установах та організаціях $є$ грубим порушенням трудового законодавства, котре може призводити до експлуатації працездатної особи, а також унеможливлюватиме забезпечення належного рівня соціальної безпеки працівника.

Особливо актуальним це питання постає відносно поліцейських як працівників, наділених особливим правовим статусом. Відповідно до ст. 94 Закону України «Про Національну поліцію України» [1] поліцейські отримують грошове забезпечення, розмір якого визначається залежно від посади, спеціального звання, строку служби в поліції, інтенсивності та умов служби, кваліфікації, наявності наукового ступеня 
або вченого звання. Порядок виплати грошового забезпечення визначає Міністр внутрішніх справ України. За поліцейськими, які тимчасово проходять службу за межами України, зберігається виплата грошового забезпечення в національній валюті та виплачується винагорода в іноземній валюті за нормами і в порядку, що визначаються Кабінетом Міністрів України. Поліцейські, відряджені до інших органів державної влади, установ, організацій та прикомандировані відповідно до цього Закону, отримують грошове забезпечення, враховуючи посадовий оклад за посадою, яку вони займають в органі, установі чи організації, до якої вони відряджені, а також інші види грошового забезпечення, визначені цим Законом. Грошове забезпечення поліцейських індексується відповідно до закону.

Згідно 3 наказом Міністерства внутрішніх справ України від 6 квітня 2016 р. № 260 «Порядок та умови виплати грошового забезпечення поліцейським Національної поліції і здобувачам вищої освіти закладів вищої освіти із специфічними умовами навчання, що здійснюють підготовку поліцейських» [2] під час переведення по службі, пов'язаному 3 переїздом до іншого населеного пункту, або переведення до іншого органу Національної поліції грошове забезпечення за попереднім місцем служби виплачується включно з днем звільнення з посади, що передує даті відбуття до нового місця служби, зазначеній у наказі по особовому складу. За призначення поліцейського на іншу посаду в одному органі поліціï грошове забезпечення виплачується за новою посадою з дня призначення на посаду, вказаного в наказі по особовому складу. Грошове забезпечення за попередньою посадою виплачується включно $з$ днем звільнення $з$ посади, зазначеним у наказі по особовому складу. За такої умови день звільнення з посади вважається останнім днем служби на відповідній посаді. Якщо в наказі по особовому складу дата призначення на посаду не зазначена, грошове забезпечення виплачується з дня підписання цього наказу. Поліцейським за час перебування у службових відрядженнях виплачується грошове забезпечення 3 розрахунку посадового окладу, установленого за основною штатною посадою, а також окладу за спеціальним званням, щомісячних додаткових видів грошового забезпечення (підвищення посадового окладу, надбавки, доплати, які мають постійний характер), преміі, яка встановлюється щомісяця, та одноразових видів грошового забезпечення (у разі ї установлення за час відрядження).

Згідно 3 Постановою Кабінету Міністрів України від 11 листопада 2015 р. за № 988 «Про грошове забезпечення поліцейських національної поліції» грошове забезпечення поліцейських складається 3 посадового окладу, окладу за спеціальним званням, щомісячних додаткових видів грошового забезпечення (підвищення посадового окладу, надбавки, доплати, які мають постійний характер), премії та одноразових додаткових видів грошового забезпечення [3].

Проаналізувавши законодавчі акти у царині цієї проблематики, ми дійшли висновку, що нині поняття «грошове забезпечення поліцейських» не визначено. Згідно з цим поняттям, представленим у наукових джерелах, грошове забезпечення персоналу органів внутрішніх справ визначено як винагороду, що виплачується за виконання ним зумовленої трудовим договором (контрактом) службово-трудової функції і складається як 3 основних виплат, які провадяться незалежно від можливостей бюджетного фінансування, так і інших додаткових його видів, які мають право встановлювати керівники органів і підрозділів внутрішніх справ у межах фонду оплати праці [4, с. 9].

Грошовому забезпеченню поліцейських притаманні загальні та 
спеціальні ознаки. До його загальних ознак зазвичай науковці відносять такі: 1) винагорода за працю; 2) може бути основним і додатковим; 3) розмір та умови винагороди визначаються нормативно або угодою сторін; 4) права та обов'язки з виплати заробітної плати виникають після укладення трудового договору (контракту). У свою чергу до специфічних ознак відносять: 1) регулювання як загальнодержавним, так i відомчими нормативними актами, в системі яких переважають перші; 2) переобтяження значною кількістю його додаткових видів, а основні його види (посадовий оклад, оклад за спеціальними званням, щомісячні додаткові види грошового забезпечення, які мають постійний характер, премії та одноразові додаткові види грошового забезпечення) в загальній сумі (без урахування індивідуальних специфічних надбавок і доплат) становлять лише 10-30\%; 3) призводить до значної диспропорції оплати праці осіб рядового та начальницького складу органів поліції; 4) на його розмір значно впливають як бюджетне фінансування, так і воля керівника; 5) джерелами його виплат $€$ як державне фінансування і фінансування органами місцевого самоврядування, так i кошти спеціальних фондів [5, c. 124]

Зважаючи на викладене, метою грошового забезпечення поліцейських $€$ забезпечення задоволення матеріальних потреб і законних інтересів поліцейських, зокрема, в позаслужбовому житті. Грунтуючись на основних пріоритетах соціальної політики України, К. К. Довбиш зазначає, що головна мета інституту оплати праці - «підвищення рівня та якості життя населення на основі стимулювання трудової активності, надання кожній працездатній людині здатностей, які дають можливість своєю працею забезпечити себе і свою сім'ю» [6, с. 4]. Водночас слід враховувати, що поліцейські $є$ особливими суб'єк- тами трудового та соціального права, виконання службових функцій якими безпосереднім чином позначається на національній безпеці держави, спроможності держави виконувати свої функціі, зокрема в соціальній сфері. Саме тому стосовно поліцейських, на відміну від працівників загалом, державою постійно застосовуються особливі заходи щодо матеріального забезпечення, спрямовані на задоволення базових та окремих похідних матеріальних потреб поліцейського (зокрема медичне, житлове, речове, продовольче та інше забезпечення). У цьому контексті можемо дійти висновку, що поліцейські виконують свої службові обов'язки в умовах задоволення державою ї базових потреб та законних інтересів (навіть тоді, коли якість такого забезпечення $€$ недостатньою, зважаючи на кризові явища в державі), тому грошове забезпечення безпосереднім чином не спрямоване на задоволення таких іхніх потреб. Інакше кажучи, мета грошового забезпечення поліцейських повинна виявлятись у забезпеченні гідного життя та існування таких службовців 3 урахуванням факту задоволення ї поточних базових потреб та інтересів державою поза грошового забезпечення, а також стимулювання поліцейського краще виконувати свої службові завдання (адже винагорода виконує й заохочувальну функцію) [7, с. 41]). Хоча припускається, що особа, яка бажає стати поліцейським, уже має високу мотивацію виконувати свої службові обов'язки, необхідно погодитись із тим, що гідне грошове забезпечення дозволяє посилити матеріальну зацікавленість у досягненні високих показників у професійній підготовці, а недооцінка достатнього рівня грошового забезпечення поліцейських веде до зниження ефективності виконання основної функції Національної поліції України - підтримання безпеки держави загалом. Більше того, мотивація діяльності поліцейських 
без застосування сучасних механізмів і методів матеріального та нематеріального заохочення не може бути максимально дієвою. Це обумовлено тим фактом, що поліцейський, як і будь-який інший працівник, потребує постійної позитивної мотивації у належному здійсненні своїх трудових (службових) обов'язків, а також у заохоченні проявів зразкового виконання таких обов'язків.

Грошове забезпечення поліцейських виконує особливі завдання i функції. Виходячи 3 особливої основної та похідної мети грошового забезпечення поліцейських, можемо дійти висновку, що основними завданнями такого забезпечення $є$ : 1) створення умов належного рівня соціальної безпеки поліцейського та його сім'̈ (зокрема формування здорового психологічного клімату в сім’і за рахунок такого забезпечення, посиленого іншими видами матеріального забезпечення), за якого така особа може повною мірою реалізувати свій трудовий потенціал на службі; 2) стимулювання високого рівня виконавської дисципліни, нетолерантності до корупції на службі, належного рівня демотивації цих осіб стосовно вчинення ними службових злочинів, а також злочинів проти інтересів держави та народу; 3) мотивування до такої служби осіб, які володіють належним рівнем трудової правосуб'єктності, високими показниками психофізіологічного здоров'я.

Стосовно функцій грошового забезпечення поліцейських ми зазначимо, беручи до уваги позиції науковців щодо функцій заробітної плати [8, с. 76-77; 9], що основними 3 них $€$ такі: 1) відтворювальна функція (переважно є головним джерелом доходу поліцейського); 2) забезпечення матеріального стимулювання поліцейського; 3) стимулююча функція (залежить від тривалості й інтенсивності служби, успіхів у виконанні завдань, від дисциплінованості службовця тощо); 4) регулююча функція (залежить від кваліфікації, звання, інших особистих характеристик поліцейського).

Висновки. На підставі викладеного вище можемо констатувати, що грошове забезпечення поліцейських виступає однією з умов ефективного та результативного виконання покладених на них відповідних завдань і функцій, оскільки достатній обсяг фінансування необхідний в усіх сферах державного управління, котрий, окрім іншого, дозволяє запобігти корупційним правопорушенням та $€$ гарантією незалежності й належного виконання державними органами, зокрема органами поліції, своїх функціональних обов'язків. Значення грошового забезпечення поліцейських визначається його завданнями, до яких слід віднести такі: забезпечення достатніх та належних матеріальних умов для життя і відпочинку; комплектування якісного особового складу органів поліції; диференціація умов і характеру праці; стимулювання праці; компенсування фізичних та інтелектуальних затрат; профілактика службових правопорушень, особливо тих, які вчиняються 3 корисливою метою. Відповідно до цього основними функціями грошового забезпечення поліцейських $є$ такі: 1) відтворювальна функція (переважно $є$ основним джерелом доходу поліцейського); 2) забезпечення матеріального стимулювання поліцейського; 3) стимулююча функція (залежить від тривалості та інтенсивності служби, успіхів у виконанні завдань, від дисциплінованості службовця тощо); 4) регулююча функція (залежить від кваліфікації, звання та інших особистих характеристик поліцейського).

Отже, грошове забезпечення поліцейських - це гарантована державою в гідному розмірі винагорода працівника, що характеризується основною (задоволення гідного життя поліцейського) та похідною (стимулювання краще виконувати свої 
службові завдання) метою, завданнями (створення умов належного рівня соціальної безпеки працівника, його сім”i; стимулювання трудової конкуренції, виконавської дисципліни тощо) та функціями (відтворювальною, забезпечувальною, стимулюючою, регулюючою) i нараховується й виплачується за виконання роботи на службі.

Нормативно-правова основа грошового забезпечення охоплює міжнародно-правові акти, норми яких стосуються оплати праці (акти про права людини та міжнародно-правові акти МОП), національні нормативно-правові акти про оплату праці та про грошове забезпечення поліцейських (законодавчого і підзаконного характеру).

У роботі розглянуто сутність $i$ значення грошового забезпечення поліцейських. Зроблено висновок, що грошове забезпечення поліцейських виступає однією з умов ефективного та результативного виконання покладених на них відповідних завдань $і$ функцій. Достатній обсяг фінансування необхідний у всіх сферах державного управління, оскільки, крім іншого, цее дозволяе запобігти корупційним правопорушенням та є гарантією незалежності й належного виконання державними органами, зокрема органами поліції, своїх функциінальних обов'язків. Значення грошового забезпечення поліцейських визначається його завданнями, до яких слід віднести: забезпечення достатніх та належних матеріальних умов життя $i$ відпочинку; комплектування якісного особового складу органів поліиіï; диференціацію умов $і$ характеру праці; стимулювання праці; компенсування фізичних та інтелектуальних затрат; профілактику службових правопорушень, особливо тих, які вчиняються з корисливою метою. Основними функиіями грошового забезпечення поліцейських є такі: 1) відтворювальна функція (переважно основне джерело доходу поліцейського); 2) забезпечення матеріального стимулювання поліцейського; 3) стимулююча функція (залежить від тривалості та інтенсивності служби, успіхів у виконанні завдань, від дисциплінованості службовия тощо); 4) регулююча функція (залежить від кваліфікаціі, звання, інших особистих характеристик поліцейського).

Грошове забезпечення поліиейських визначено як гарантована державою в гідному розмірі винагорода працівника, що характеризується основною (задоволення гідного життя поліцейського) та похідною (стимулювання краще виконувати свої службові завдання) метою, завданнями (створення умов належного рівня соціальної безпеки працівника, його сім' $і$; стимулювання трудової конкуренцї, виконавської дисципліни тощо) та функціями (відтворювальною, забезпечувальною, стимулюючою, регулюючою) $i$ нараховується й виплачується за виконання роботи на службі. Нормативно-правова основа грошового забезпечення охоплюе міжнародно-правові акти, норми яких стосуються оплати праці (акти про права людини та міжнародно-правові акти МОП), національні нормативно-правові акти про оплату праці та про грошове забезпечення поліцейських (законодавчого $i$ підзаконного характеру).

Ключові слова: поліцейський, соціальний захист, матеріальне забезпечення, грошове забезпечення.

Masalova T. On the concept of money security of police

The paper considers the essence and significance of financial support for police officers. It is concluded that the financial support of police officers is one of the conditions for effective and efficient performance of 
their respective tasks and functions. Because sufficient funding is needed in all areas of public administration, as it, among other things, prevents corruption offenses and guarantees the independence and proper performance of public functions, in particular by the police,. The value of financial support for police officers is determined by its tasks, which should include: providing sufficient and appropriate material conditions for life and leisure; staffing of high-quality police personnel; differentiation of working conditions and nature; labor incentives; compensation of physical and intellectual costs; prevention of official offenses, especially those committed for selfish purposes. The main functions are: 1) reproductive function (mainly is the main source of income for the police); 2) providing material incentives for police officers; 3) stimulating function (depends on the duration and intensity of service, success in performing tasks, on the discipline of the employee, etc.); 4) regulatory function (depends on the qualifications, rank and other personal characteristics of the police officer).

Cash security of police officers is defined as a state-guaranteed reward of an employee, characterized by the main (satisfaction of a decent life of a police officer) and derivative (incentives to better perform their duties) purpose, tasks (creating conditions for proper social security of the employee, his family; labor competition, executive discipline, etc.) and functions (reproductive, providing, stimulating, regulating) and is accrued and paid for the performance of work in the service. The legal framework for cash coverage includes international legal acts related to remuneration (human rights acts and ILO international legal acts), national legal acts on remuneration of labor and on police security (legislative and by-laws).

Key words: policeman, social protection, material security, financial security.

\section{Література}

1. Про Національну поліцію: Закон України від 02.07.2015 p. № 580-VIII. Відомості Верховної Ради України. 2015. № 40-41. Cm. 379 .

2. Порядок та умови виплати грошового забезпечення поліцейським Національної полічії та здобувачам вищої освіти закладів вищої освіти із специфічними умовами навчання, щз здійснюють підготовку поліцейських: наказ Міністерства внутрішніх справ України від 06.04.2016 р. № 2606 квітня 2016 p., № 260. URL: https: / / zakon.rada.gov.ua/ laws / show / z0669-16\#Text

3. Про грошове забезпечення поліцзейських національної поліції: постанова Кабінету Міністрів України від 11.11 .2015 p. № 988. URL: https:// zakon.rada.gov.ua/laws/show/988-2015$\%$ DO $\%$ BF\#Text

4. Музичук О. Сутність та особливості грошового забезпечення персоналу органів внутрішніх справ. Вісник Харківського національного університету внуmpiшнiх справ. 2007. Bun. 37. C. 5-11.

5. Марусевич Д. О. Теоретичні засади адміністративно-правового регулювання грошового забезпечення поліцейських. Науковий вісник публічного та приватного права. 2017. Bun. 3. С. 123-128.

6. Довбиш К. К. Принщипи правового регулювання оплати праці: дис. ... канд. юрид. наук: 12.00.05. Харків, 2017. 191 с.

7. Арсентьева О. С. Види та форми заохочень за трудові досягнення. Актуальні проблеми права: теорія і практика. 2016. № 32. C. 41-48.

8. Колот A. М. Теоретико-методологічні аспекти класифікації й змісту функцій заробітної плати. Україна: аспекти праціi. 2000. № 6. С. 15-19.

9. Малищька І. Д. Функиї̈ заробітної плати та стан їх виконання в Україні. Держава і право. 2011. Bun.51. C. 409-413. 